\title{
Molla Bedreddin Sancar ve Sünnetle Tefsir Anlayışı (Bakara Suresi Bağlamında)*
}

\author{
Molla Bedreddin Sancar and His Understanding of Quranic Exgesis with Sunnah \\ (In the Context of Surah Baqarah)
}

Esat ÖZCAN**

Öz

Abstract

Siirt'in Tillo ilçesinde dünyaya gelen Molla Bedreddin Molla Bedreddin Sancar, born in Tillo, district of Siirt, is a Sancar, Şark medrese usulüne göre ilim tahsil eden, yine scholar and exegete (mufassir), who got an education in aynı usule göre talebe yetiştiren, yetiştirmeyi sürdüren the way of Eastern Madrasah and teaches his students bir âlim ve müfessirdir. Siirt yöresinde Seyda Molla in the same way. Sancar, known as Sayda Molla Bedri/Bedreddin olarak tanınan Sancar, üçü tefsir Bedri/Bedreddin in Siirt, write three Quranic exegeses as alanında olmak üzere birkaç eser kaleme almıştır. well as a few works. Sancar interpret Quran using Sancar, değişik metotlarla Kur'ân'ı tefsir etmeye various methods. One of these methods is the exegesis çalışmıştır. Bunlardan biri de Asr-ı saadetten itibaren en by sunnah containing the Prophet's words, acts, and önemli tefsir metotlarından kabul edilen $\mathrm{Hz}$. approvals, which has been one of the important methods Peygamber'in söz, fiil ve takrirlerinden since the period of al-asr al-saadah. In the paper, we first (onaylamalarından) oluşan sünnetidir. Çalışmada önce give brief information regarding the mufassir's life and müfessirin hayatı ve eserleri hakkında kısa bilgilere yer works, then present Sancar's understanding of exegesis verilecek, ardından Sancar'ın sünnetle tefsir anlayışına with the sunnah. We deal with the Quranic exegeses he geçilecektir. Bu kapsamda müfessirin Ebde'u'l-beyân adlı made using the sunnah in the context of Surah aleserinde Bakara suresi çerçevesinde sünnetle yaptığı Baqarah in his work Abdau al-bayan. We also determine tefsirler üzerinde durulacak, söz konusu tefsir metoduna the purposes for which he made use of the exegesis hangi amaçlarla müracaat ettiği tespit edilmeye method and give concrete examples regarding his çalışılacak ve konu örneklerle somutlaştırılacaktır. usage. The sources of the paper consist of the works Çalışmanın kaynaklarını, başta müfessirin hal providing his biograph, the academic research tercümesini veren eserler, kendisi ve eserleri hakkında conducted on him and his works, and his Quranic yapılan akademik çalışmalar ile onun mezkûr tefsiri teşkil exegesis. We also take into consideration the exegesis edecektir. Öte yandan müfessirin tefsir, hadis kaynakları and hadith sources of the exegete, and the works on the ile Kur'ân ilimleri ve tefsir usulü alanında yazılan eserler Quranic sciences (ulum al-Quran) and the methodology de başvurulacak kaynaklar olacaktır. of Quranic exegesis (usul al-tafsir)

Anahtar Kelimeler: Tefsir, Sünnet, Sünnetle Tefsir, Keywords: Quranic Exegesis, Sunnah, Exegesis with Molla Bedreddin Sancar, Ebde'u'l-beyân.

Sunnah, Molla Bedreddin Sancar, Abdau al-Bayan.

\section{Giriş}

Sünnet, Hz. Peygamber’in söz, fiil ve takrirlerine denilmektedir. ${ }^{1}$ Âlimlerin çoğuna göre sünnet de Kur’ân gibi dinin kaynağıdır. Zira sünnet, Kur’ân’ın beyan ettiklerini pekiştirmekte; mücmel, 'âm ve mutlak olarak belirttiklerini tebyin, tahsis ve takyid etmekte ve Kur’ân’da bulunmayan bazı ilave bilgiler vermektedir. ${ }^{2}$ Bunun için âlimler, Kur’ân’ı tefsir etmeye, ondan hükümler istinbât etmeye çalışırken sünnete

* Geliş Tarihi: 19.04.2021, Kabul Tarihi: 28.06.2021

** Dr. Öğr. Üyesi, Siirt Üniversitesi İlahiyat Fakültesi, Tefsir Anabilim Dalı, esatozcan@siirt.edu.tr, Orcid: 0000-0003-0974-8325.

1 Seyyid Şerîf el-Cürcânî, et-Ta ‘rîfât (Beyrut: Dârü'l-Kütübi’l-'İlmiyye, 1983), 122.

2 Muhammed Lokman es-Selefî, Mekânetü’s-sünne fi't-teşrî'i’l-İslâmî (Riyad: Dârü'd-Dâ‘î, 1999), 111-1112. 
başvurdular ve sünnet olmadan Kur’ân’ı doğru bir şekilde anlamanın çok zor, hatta imkânsız olduğunu ifade ettiler. ${ }^{3}$

Bu âlimlerden biri de bu çağın müfessirlerinden Molla Bedreddin Sancar’dır. Sancar, Ebde‘u’l-beyân adıyla kaleme aldığı eserinde tefsirle ilgili rivayetleri naklettiği gibi kendisi de ayetleri çeşitli metotlarla tefsir etmeye çalışmıştır. Sancar’ın kullandığı en önemli tefsir kaynaklarından biri de sünnettir.

Çalışmada önce Sancar’ın hayatı hakkında bilgi verilecek, ardından onun başta Ebde‘u'l-beyân adlı tefsiri olmak üzere diğer eserleri tanıtılacaktır. Daha sonra Sancar'ın söz konusu tefsirinin Bakara suresinde sünnetle yaptığı tefsirleri ele alınacaktır. Bu kapsamda onun hangi saiklerle bu tefsir metodunu kullandığı tespit edilmeye çalışılacak, konu örnekler üzerinde somutlaştırılacaktır.

Müfessirin ismi, eserleri üzerine “Ebü’l-Berekât Muhammed Bedreddin etTillovî” şeklinde kaydedildiği için kaynakça ve dipnotlarda bu isim tercih edilecektir.

\section{MOLLA BEDREDDIN SANCAR}

\subsection{Hayatı}

Sancar, ilmin revaçta olduğu, çok sayıda âlimin ve ilim merkezinin bulunduğu Siirt bölgesinde ve Osmanlı’nın tesirinin devam ettiği bir dönemde dünyaya gelmiştir. Ayrıca o, ilim ehli bir ailede yetişmiştir. $\mathrm{Bu}$ da onun erken yaşlardan itibaren ilim tahsiliyle meşgul olmasına ve genç sayılabilecek bir yaşta iyi bir şekilde yetişmesine vesile olmuştur.

Sancar, hal tercemesini yazdığı es-Sîretü'z-zâtiyye adlı küçük eserinde Türkiye’nin Şark vilayetlerinden Siirt'in Tillo ilçesinde, Recep 1343/Şubat 1925 senesinde $^{4}$ dünyaya geldiğini söylemektedir. ${ }^{5}$

3 Fahreddin Muhammed b. Ömer er-Râzî, Mefâtîhu'l-gayb (et-Tefsîrü'l-kebîr) (Beyrut: Dâru İhyâ'i’tTürâsi'l-‘Arabî, ts.), 20/212; Muhammed İzzet Derveze, et-Tefsîrü'l-hadîs (Kahire: Dâru İhyâ'i'lKütübi'l-‘Arabiyye, ts.), 5/138-139.

4 Ebü'l-Berekât Muhammed Bedreddin et-Tillovî, el-Vaslyyetü'l- 'âmme ve yelîhâ el-Vasâye'l- 'aşere'ddürer li'l-ebnâ'i'l- 'aşereti'l-gurer ve yelîhâ Şükürnâme (b.y.: y.y., ts.), 30.

5 Ebü'l-Berekât Muhammed Bedreddin et-Tillovî, es-Sîretü'z-zâtiyye ve yelîhâ Vastyettüh (İstanbul: Dârü'ş-Şafaka, 2013), 3. 
Sancar, beş yaşlarında iken Tillolu Molla Halil’in (öl. 1990) yanında Kur’ân, Nureddin Muhammed b. Abdülaziz’e (öl. ?) nispet edilen Mevlîd-i Nebî ve Erzurumlu İbrahim Hakkı’nın (öl. 1194/1780) ‘Akîdetü’l-imân risalesini okumuş ve Arapça yazı yazmayı öğrenmiştir. Sancar, yedi yaşlarında iken söz konusu dönemde üç yıllık ${ }^{6}$ olan ilkokula başlamıştır. İlkokulda okurken Arabî tahsilini ihmal etmemiş, yaz tatillerinde mezkûr hocasından ders almaya devam etmiştir. Bu süre zarfında medrese usulüne göre takip edilen fıkıh, sarf ve nahiv ilimlerine dair küçük risaleleri tahsil etmiştir. Bir müddet Molla Muhammed ed-Dirşevî (öl. ?), Molla Yahya en-Nîvilî (öl. 1960) ve Molla Abdülaziz (öl. ?) gibi hocaların yanında okumaya devam eden Sancar, 1939 senesinde babası tarafından Halenze (Bağtepe) köyünde tedris faaliyetinde bulunan Molla Abdülhakim’in (öl. 1965) medresesine götürülmüştür. Sancar, Halenze’deki tahsili esnasında, 1944 yılında kısa bir ara Bitlis iline bağlı Norşin (Güroymak) ilçesindeki Şeyh Nasır’ın (öl. ?) yanında okumuştur. ${ }^{7}$

1951-1953 yıllarındaki askerlik vazifesinden sonra Halenze'de, Molla Abdülhakim'in yanında okumaya devam eden Sancar, söz konusu hocasından ilmi icazetini aldıktan sonra Tillo’da, Şeyh Mustafa el-Fânî (öl. 1799) Medresesi’nde tedris faaliyetine başlamıştır. ${ }^{8}$

1959 senesinin Ocak ayında Tillo Ulu Camii’nin imam-hatiplik görevine atanan Sancar, Şeyh Mustafa el-Fânî medresesindeki tedris faaliyetini ve mezkûr camideki imam-hatiplik görevini on beş yıl sürdürmüştür. ${ }^{9}$

Sancar, 1971 senesinde Siirt'in Ulu Camii'ne İmam-Hatip olarak tayin edildikten sonra el-Fahr Medresesi’nde talebe yetiştirmeye başlamıştır. 1995 yılında yaş haddinden emekli olana kadar bu camideki imam-hatiplik görevini sürdürmüş, emeklilikten sonra cemaatin ısrarı üzerine söz konusu camide Cuma hutbesini okumaya ve Cuma namazlarını kıldırmaya devam etmiştir. ${ }^{10}$

\footnotetext{
6 Adil Türkoğlu, “Cumhuriyet Döneminde İlköğretimin Gelişimi”, Cumhuriyet Dönemi Eğitim Politikaları Sempozyumu, ed. Murat Parlak (Ankara: TDK Yayınları, 2010), 81.

7 Tillovî, es-Sîretü'z-zâtiyye, 7, 12-13, 14, 16, 23; Tillovî, el-Vastyyetü'l-'âmme, 30-31.

8 Tillovî, es-Sîretü'z-zâtiyye, 27.

9 Tillovî, es-Sîretü'z-zâtiyye, 28-29.

10 Tillovî, el-Vasıyyetü'l-'âmme, 34.
} 
Sancar'ın zamanı ibadet etmek, Kur'ân okumak, talebelere ders okutmak ve kitap yazmakla geçmektedir. Zaman zaman kendisini ziyaret edenlerle sohbet etmektedir. $^{11}$

\subsection{Eserleri}

Önce Sancar’ın sünnetle tefsir anlayışını inceleyeceğimiz Ebde‘u’l-beyân adlı tefsirinin üzerinde duracağız, daha sonra başta tefsir konusundaki diğer eserleri ile inanç, ahlak ve sarf alanındaki çalışmalarını kısaca tanıtmaya çalışacağız.

\section{Ebde‘u’l-beyân li-cemî‘i âyi’l-Kur’ân}

Arapça olarak kaleme alınan eser, bir cilt halinde dört defa basılmıştır. Eserin 2016 senesinde, Beyrut’ta yapılan son baskısı, 1327 sayfadan oluşmaktadır.

Eser, meşhur tefsirlerden yararlanılarak kaleme alınmış, bir nevi onlar ihtisar edilmiş ve gerekli bazı bilgilerle zenginleştirilmiştir. Nitekim eserin mukaddimesinde, Fahreddin er-Râzî (öl. 606/1210) (Mefâtîhu'l-gayb/et-Tefsîrü'l-kebîr), Kurtubî (öl. 671/1273) (el-Câmi` li-ahkâmi’l-Kur'ân), Beyzâvî (öl. 685/1286) (Envârü't-tenzîl ve esrârü't-te’vîl), Nesefî (öl. 710/1310) (Medârikü't-tenzîl ve hakâ'iku't-te’vîl), Hâzin (öl. 741/1341) (Lübâbü’t-te’vîl fî me‘âni’t-tenzîl), İbn Kesîr (öl. 774/1373) (Tefsîrü’lKur'âni’l-‘azîm), Celâleddin el-Mahallî (öl. 864/1459) ve Celâleddin es-Süyûtî’nin (öl. 911/1505) (Celâleyn) tefsirlerinden, Celâleyn tefsirinin haşiyelerinden, Ebüssuûd Efendi (öl. 982/1574) (İrşâdü’l-‘akli’s-selîm ilâ mezâya’l-kitâbi’l-kerîm), Âlûsî (öl. 1270/1854) (Rûhu’l-me‘ânî fî tefsîri’l-Kur'âni’l-‘azîm ve’s-seb'i’l-mesânî) ve Sâbûnî (öl. 2021) (Safvetü't-tefâsîr) gibi meşhur müfessirlerin çalışmalarından yararlanıldığı ifade edilmiştir. $^{12}$

11 Tillovî’nin hayatı hakkında ayrıca bk. Nurettin Turgay, "Müfessir Muhammed Bedreddin Sancar Hayatı Eserleri ve Tefsirciliği”, Uluslararası Siirt Sempozyumu (İzmir: Birleşik Matbaa, 2007), 266267; Hasan Çağlar, Bedreddin Sancar ve Ebdeu'l-beyân li cemîi âyi'l-Kur'ân Adlı Tefsiri (Șanlıurfa: Harran Üniversitesi, Sosyal Bilimler Enstitüsü, Yüksek Lisans Tezi, 2010), 8-15; Harun Öğmüş, "Bedreddin Sancar ve Ebdau'l-beyân Adındaki Tefsiri”, Uluslararası Şırnak ve Çevresi Sempozyumu, ed. M. Nesim Doru (Ankara: MRK Bask1, 2010), 730-731.

12 Ebü'l-Berekât Muhammed Bedreddin et-Tillovî, Ebde 'u'l-beyân li-cemî‘i âyi’l-Kur'ân (Beyrut: elMektebetü'l-Hâşimiyye, 2016), 9. 
Tefsirin uzun olmamasına azami dikkat edilmiştir. Bundan dolayı konular çok kısa ele alınmış, aynı konu tekrar edilmemiştir. Bunun için okuyucu sık sık önceki, sonraki veya tefsirin sonunda yer verilen ek açıklamalara yönlendirilmiştir. $\mathrm{Bu}$ da okuyucunun tefsirden istifade etmesini zorlaştırmıştır. Tefsirde genellikle ‘Âsım’ın Hafs rivayeti takip edilmiş, diğer kıraat ve rivayetlere yer verilmemiştir. ${ }^{13}$

Eserin mukaddimesinde Kur’ân tarif edilmiş, ardından onun 114 sureden oluştuğu, ayetlerin sayısının 6000'den fazla olduğu, bu fazlalık konusunda ihtilaf bulunduğu ifade edilmiş ve bu konudaki bazı görüşlere değinilmiştir. Mukaddimede ilk ve son inen ayetler hakkında da bilgi verilmiştir. ${ }^{14}$

Tefsirin dipnotlarında bazı taliklere yer verilmiş, bu dipnotlardaki bilgiler genellikle Âlûsî’nin Rûhu'l-me‘ânî veya Sâbûnî’nin Safvetü't-tefâsîr'inden alınmıştır. Bu dipnotlar ayrı bir eser kabul edilerek “Kalâ'idü’l-cumân fî cîdi Ebde‘i’l-Beyân” şeklinde isimlendirilmiştir. ${ }^{15}$

Eser, uzun tefsirleri okumak için yeteri kadar zamanı olmayan ve ilgili tefsirlerden az da olsa haberdar olmak isteyen okuyuculara yöneliktir. Eser, aynı zamanda medreselerde ders kitabı olarak okutulan Beyzâvî’nin Envârü't-tenzîl adlı eserinin yerine okutulabilecek bir tefsirdir. Zira eserde, medreselerde okutulan sarf, nahiv ve belagat ilimleri ile tefsir yapılmaya önem verilmiştir.

$\mathrm{Bu}$ da medrese öğrencilerine teorik olarak aktarılan söz konusu ilimlerle ilgili kuralların uygulanmasına vesile olacaktır. Nitekim Sancar, tefsirini kendi talebelerine okutmakta ve derslerde söz konusu ilimlerin kuralları üzerinde durmaktadır.

\section{Hulâsatü’l-beyân li-cemî‘i âyi’l-Kur’ân}

Sancar, bu tefsirinin Ebde‘u'l-beyân adlı eserinin bir ihtisarı olduğunu söylemiştir. Ancak bu eserinin mukaddimesinde Ebde‘u’l-beyân’ın kaynaklarına

13 Tillovî, Ebde 'u’l-beyân, 10.

14 Tillovî, Ebde 'u'l-beyân, 11-12.

15 Tillovî, Ebde' 'u'l-beyân, 10. Sancar'ın bu tefsiri hakkında bk. Turgay, "Müfessir Muhammed Bedreddin Sancar", 267-270; Çağlar, Bedreddin Sancar, 18-125; Uğur Erman, "Siirt Medreselerinde İcâzetnâme Sonrası Okutulan Eserler ve İçerikleri”, Siirt Üniversitesi Sosyal Bilimler Enstitüsü Dergisi 10 (2017), 592-593. 
ilaveten Zemahşerî’nin (öl. 538/1144) el-Keşşâf 'an hakâ'iki't-tenzîl ve İsmail Hakki elBursevî’nin (öl. 1137/1725) Rûhu’l-beyân isimli tefsirlerini de zikretmiştir. Öte yandan Ebde‘u’l-beyân’ın mukaddimesinde kaynaklarını sıralarken Celâleyn ve haşiyeleri ifadesi yerine, bu eserinin mukaddimesinde Celâleyn ve Cemel haşiyesi tabirini kullanmıştır. ${ }^{16}$ Anlaşıldığı kadarıyla iki tefsirin kaynakları aynıdır. Zira açıkladığımız gibi Hulâsatü'l-beyân, Ebde‘u'l-beyân'ın muhtasarıdır. Muhtemelen müfessir, kaynaklarının tamamını değil; bir kısmını zikretmek istemiş, bunun için böyle bir fark ortaya çıkmıştır. Arapça olan Hulâsatü'l-beyân, el-Mektebetü’l-Hâşimiyye tarafından bir cilt halinde ve 606 sayfa olarak 2017 yılında basılmıştır.

\section{Bedî‘u'l-beyân limâ 'asâ en yahfâ fi'l-Kur'ân}

Eserde, Kur’ân’ın anlaşılmama veya yanlış anlaşılma ihtimali bulunan kelime ve ifadelerine yer verilmektedir.

Kur’ân’da bir kelimenin farklı yerlerde aynı veya farklı manalarda kullanılması, bu gibi çalışmalara olan ihtiyacı artırmaktadır. Nitekim tefsir tarihi boyunca "vücûh ve nezâir” denilen bu konuya dair birçok çalışma yapılmış ve yapılmaya devam etmektedir. Müfessir, bu eserinde özellikle Muhammed Fâris Berekât'ın (öl. ?) telif ettiği el-Murşid ilâ âyâti’l Kur'ân ve kelimâtih adlı eserinden yararlandığını ifade etmektedir. ${ }^{17}$

Eserde kelimeler, alfabetik sıraya göre ele alınmış ve kırmızı kalemle yazılmıştır. Bu da aranan kelimenin kolayca bulunmasına yardımcı olmuştur. Aynı kökten ve aynı manaya gelen kelimelerin sadece bir şekline yer verilmiş, diğer şekilleri ise öteki izahlara yönlendirilmiştir. Eserde Kur'ân'da yer alan 6000'den fazla kelime, ifade ve cümle ele alınmıştır. Farklı yerlerde farklı manalarda kullanılan kelimelerin ilgili yere uygun manası verilmiştir. Ayrıca bazı durumlarda kelimelerin i'rabına, ayetlerden istinbât edilebilen fıkhî meselelere ve fıkıh mezheplerinin ihtilaflarına değinilmiştir. Öte yandan Kur’ân'da ismi zikredilen peygamberler hakkında kısaca bilgi verilmiştir. ${ }^{18}$ Dört

16 Ebü’l-Berekât Muhammed Bedreddin et-Tillovî, Hulâsatü'l-beyân li-cemî‘i âyi'l-Kur'ân (b.y.: elMektebetü'l-Hâşimiyye, 2017), Mukaddime/2.

17 Ebü'l-Berekât Muhammed Bedreddin et-Tillovî, Bedî'u'l-beyân limâ 'asâ en yahfâ fi'l-Kur'ân (İstanbul: Kahraman Yayınları, 2010), 11.

18 Tillovî, Bedî‘u’l-beyân, 14, 15, 18, 169, 218, 235; Çağlar, Bedreddin Sancar, 21-22. 
defa basılan eserin Kahraman Yayınları tarafından ve 2010 senesinde yapılan son baskısı, 320 sayfadan müteşekkildir.

\section{4. 'Akîdetü’l-mü'mini’s-sedîde}

Bu eser, Ehl-i sünnet inanç sistemine dair kaleme alınmış küçük bir risale mahiyetindedir. Kolay bir şekilde ezberlenebilsin diye manzum olarak telif edilen eser, 54 beyitten oluşmaktadır.

\section{Hulâsatü't-tasrîf'}

Eser, isminden de anlaşıldığı gibi sarf ilmiyle ilgilidir. Eserde sarf ilmi konusunda bilinmesi gereken konular özlü bir şekilde ele alınmıştır. 28 sayfalık küçük bir risale şeklinde olan eserin dipnot kısmında, bahsi geçen konulara dair bazı izahlara, örneklere ve eklemelere yer verilmiştir.

6. el-Vasıyye

Müfessir, 9 sayfalık küçük bir risale şeklinde olan bu eserinde çocuklarına ve diğer Müslümanlara kısaca bazı nasihatlerde bulunmuştur. Bu üç risale, küçük bir eser halinde Şefkat Yayınları tarafından basılmıştır.

7. es-Sîretü'z-zâtiyye

Müfessir, 29 sayfalık küçük bir risale olan bu eserinde hayatı hakkında bilgi aktarmıştır. Özellikle öğrencilik yaşantısına ve öğrenciliği süresince çektiği sıkıntılara yer vermiştir. Eserin ikinci baskısı, daha önce bahsi geçen müfessirin vasiyetiyle birlikte, Şefkat Yayınları tarafından 2013 yılında gerçekleştirilmiştir.

\section{8. el-Vasiyyetü'l-'âmme}

Eser, müfessirin Müslümanlara yaptığı nasihatlerden oluşan ve 9 sayfadan ibaret olan küçük bir risaledir. Risalede önce vasiyet etmenin sünnet olduğu belirtilmiş ve bu konunun öneminin üzerinde durulmuştur. Risalede ilk ve üzerinde en fazla durulan nasihat takvadır.

9. el-Vasâye'l- 'aşer li'l-ebnâ'i'aşereti'l-gurer 
Bazı nasihatler içeren risale, 11 kasideden ve 9 sayfadan müteşekkildir. Müfessir, bu kasidelerin her birini, bir erkek evladına (küçük oğlu Mahmut Sancar için iki kaside) hitaben kaleme almıştır. Onuncu kaside ise müfessirin torunu (oğlu Molla Nureddin Sancar’ın oğlu) Dr. Mustafa Sancar’a yöneliktir.

\section{0. Şükürnâme}

9 Sayfadan oluşan bu risale, tahdîs-i nimet babından kaleme alınmıştır. Müfessir, bu risalesinde Allah Teâlâ'nın kendisine verdiği nimetleri sayarak ona teşekkür etmektedir. Müfessirin bu eseri, Allah Teâlâ'nın nimetlerini görmeyen, dolayısıyla yeteri kadar şükürde bulunmayan insanlar için çok önemlidir. Zira müellif bu eserinde insanın hiç düşünmediği, küçük gördüğü, haddi zatında büyük olan nimetleri saymış ve şükran duygularını ifade etmiştir. Önceki iki risaleyle birlikte tab‘ edilen bu eserin üzerinde baskı yeri, yayın evi ve tarihi hakkında herhangi bir bilgi yer almamaktadır.

\section{1. er-Rahalât ile'd-diyâri'l-mukaddese}

Sancar, bu eserinde hac ve umre münasebetiyle kutsal topraklara yaptığı yolcuklarından bahsetmiştir. Toplam dört yolculuğunu ele almış, gidişten dönüşe kadar önem verdiği bütün hususlara değinmiştir. 87 sayfadan ibaret olan ve daha önce tanıttığımız müfessirin vasiyetiyle birlikte basılan eserin üzerinde baskı yeri, tarihi ve yayın evine dair herhangi bir malumat yer almamaktadır.

Sancar, bu eserlerle birlikte Doğu medreselerinde ders kitabı olarak okutulan birçok eser üzerine şerh, haşiye ve talikler kaleme almıştır. ${ }^{19}$ Ayrıca mersiye, mektup vb. vesilelerle çok sayıda Arapça şiirler yazmıştır. Şiirleri bir divanda toplanmış; ancak daha yayımlanmamıştır. ${ }^{20}$

19 Tillovî’nin eserleri için ayrıca bk. Turgay, "Müfessir Muhammed Bedreddin Sancar”, 267; Çağlar, Bedreddin Sancar, 15-17.

20 Mehmet Akkuş, "Ahmet Emre Yetkin'in Siirtli Molla Bedreddin Sancar'a Gönderdiği Şiirler”, Uluslararası Amasya Âlimleri Sempozyumu, ed. Şuayip Özdemir - Ayşegül Gün (Ankara: KIBATEK Yayınları, 2017), 2/12. 


\section{MOLLA BEDREDDIN SANCAR'IN SÜNNETLE TEFSİR ANLAYIŞI}

Sancar, bu tefsir metodunu kullanırken diğer birçok klasik müfessir gibi bazen sünnetle tefsir yaptığını söylememekte, hadislere yer vermemekte ve onlara işaret etmemektedir. Ayrıca kaynak gösterdiği hadislerin senetlerine ve sıhhat durumuna dair herhangi bir bilgi vermemektedir. Öte yandan müfessir, eserinin kısa olması için özellikle ilave bilgiler veren hadisleri metnin içinde değil, dipnotlarda kaydetmektedir. ${ }^{21}$

Örneklerimizin çoğunu onun tefsirinin kendisinde ve hadislerin metinlerini vererek veya söz konusu bilginin hadislerde yer aldığını kaydederek yaptığı tefsirlerden seçeceğiz. Müfessir, ayetlerde verilen bilgileri pekiştirmek, verilmek istenen mesajlara dikkat çekmek, neshedilen hükümleri belirtmek, ayetlerin yanlış anlaşılmasının önüne geçmek, ayetlerdeki âm, mutlak ve mücmel ifadeleri tahsis, takyid ve tebyin etmek, müteşâbih ayetlerin tevilini yapmak ve Kur’ân'da olmayan bilgilere yer vermek için sünnete başvurmaktadır.

\subsection{Ayette Verilen Bilgiyi Pekiştirmesi}

Sünnetin önemli bir kısmı, Kur’ân’da açıkça veya zımnen verilen bilgileri pekiştiren hadislerden oluşmaktadır. Zira Hz. Peygamber'in en önemli görevlerinden biri ayetlerde ${ }^{22}$ de kaydedildiği gibi Kur'ân’ı açıklamak ve onun ne dediğini, ne demek istediğini izah etmektir. Hz. Peygamber, bu beyan görevini sözlü, uygulamalı ve onaylama şeklinde yapmıştır. Müfessirin bu husustaki tefsirlerini iki örnek üzerinde açıklamaya çalışacağız.

\section{1. "Sabrederek ve namaz kılarak yardım dileyin.”23}

Müfessir, bu ayeti “Sabır ve özellikle namazla yardım dileyin.” şeklinde tefsir ederek namazın önemine işaret etmekte, ardından namazın, tüm ibadetleri içinde barındırdığına ve Allah Teâlâ’ya teslim olmanın zirvesi olduğuna işaret etmektedir.

\footnotetext{
Tillovî, Ebde 'u’l-beyân, 76, 79, 80.

Bk. İbrahim 14/4; en-Nahl 16/44, 64.

el-Bakara 2/45.
} 
Daha sonra "Hz. Peygamber, sıkıntılı durumlarda namaza koşardı." ${ }^{24}$ hadisiyle ayette verilen bilgiyi teyit etmektedir. ${ }^{25}$ Zira bu hadis, her konuda en büyük yardım vesilesinin namaz olduğunu açıkça göstermektedir.

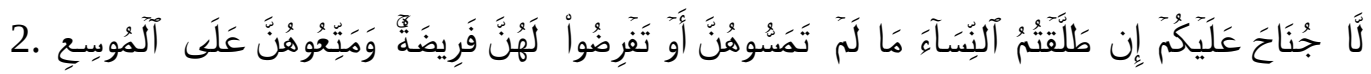

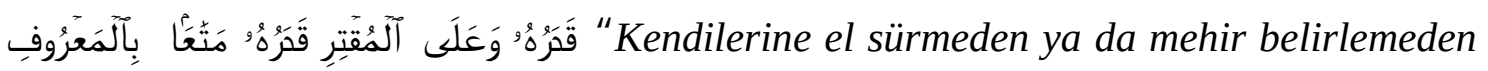
kadınları boşarsanız size bir günah yoktur. (Bu durumda) -eli geniş olan gücüne göre, eli dar olan da gücüne göre olmak üzere- onlara bir geçimlik verin. Bu, iyilik yapanlar üzerinde bir borçtur.”26

$\mathrm{Bu}$ ayet, mehir belirlenmeden ve ilişki yaşanmadan yapılan boşanmalarla ilgilidir. Ayet, bu durumda mehr-i mislin ${ }^{27}$ ödenmesine gerek olmadığını; ancak kadına bir şeylerin verilmesi gerektiğini kaydetmekte, bunun erkeğin durumuna ve örfe göre belirlenmesini istemektedir. Müfessir, verilecek olan miktarın kadının değil; erkeğin sosyal durumuna göre belirleneceğini; çünkü ayetin bunu emrettiğini ve $\mathrm{Hz}$.

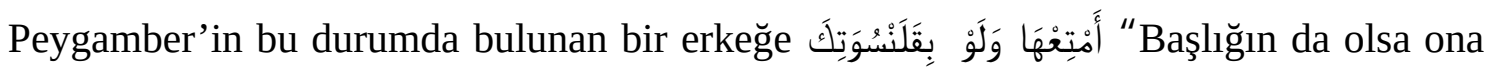
bir şeyler ver." ${ }^{28}$ dediğini söyleyerek ayetten anlaşılan manayı hadisle teyit etmektedir. ${ }^{29}$

\subsection{Verilmek İstenen Mesaja Dikkat Çekmesi}

Her sözde olduğu gibi Allah Teâlâ'nın kelamında da bazen söylenmek istenen birtakım hususlar, hemen fark edilmemekte, dolayısıyla bir izaha gerek duyulmaktadır. Sünnetin bir kısmı da Allah Teâlâ’nın özellikle kıssalar vasıtasıyla vermek istediği

\footnotetext{
24 Muhammed Enver Şâh Hüseynî Keşmîrî, Feydu'l-bârî 'alâ Sahîhi’l-Buhârî, thk. Muhammed Bedir 'Âlem el-Mîrtehî (Beyrut: Dârü'l-Kütübi'l-'İlmiyye, 2005), 2/506.

25 Tillovî, Ebde 'u'l-beyân, 37.

26 el-Bakara 2/236.

27 İki tür mehir vardır: Mehr-i müsemmâ ve mehr-i misil. Birincisi nikâh akdinden önce veya onun esnasında belirtilen mehirdir. İkincisi ise mehri belirtilmeyen kadına verilmesi gereken mehir miktarıdır. Mehr-i misil, evlenen kadının sosyal statüsündeki diğer kadınların ortalama mehir miktarıdır. M Âkif Aydın, "Mehir", Türkiye Diyanet Vakfi İslâm Ansiklopedisi (Ankara: TDV Yayınları, 2003), 28/390.

28 Rivayete göre Hz. Peygamber, evlendiği kadını ilişki yaşamadan boşayan bir adama "Ona bir şeyler ver." demiş; adamın çok fakir olduğunu, elinde herhangi bir şeyin bulunmadığını söylemesi üzerine "Başlığını ver." buyurmuştur. Abdullah b. Yusuf ez-Zeyle‘î, Tahrîcü'l-ehâdîs ve'l-âsâr el-vâkı 'a fî Tefsîri'l-Keşşâf li'z-Zemahşerî, thk. Abdullah b. Abdurrahman es-Sa'd (Riyad: Dâru İbn Huzeyme, 1414/1993-1994), 1/150.

29 Tillovî, Ebde 'u'l-beyân, 105.
} 
mesajlara dikkat çekmektedir. Müfessir bahusus tefsirin dipnotunda bu konuları sünnetle açıklamaktadır. Ancak daha önce de ifade ettiğimiz gibi örneklerimizi tefsirin kendisinden vermeye çalışacağız.

1 فَفَبَحُوهَا وَمَا كَاحُواْ يَفَلُونَ "Nihayet onu (sığırı) kestiler. Neredeyse bunu yapmayacaklardı."30

Bakara suresi 67-74 ayetlerinde İsrâiloğullarıyla ilgili bir kıssaya yer verilmektedir. Müfessir bu ayetin tefsirinde Hz. Peygamber’in, İsrâiloğullarının gereksiz yere işi yokuşa sürdüklerini, soru sormak yerine emri hemen yerine getirmeleri gerektiğini ve onlar zorlaştırdıkça Allah Teâlâ da onlara zorluk çıkardığını ${ }^{31}$ söylediğini belirterek ayette verilen mesaja dikkat çekmektedir. ${ }^{32}$ Buna göre esas olan, verilen emri hemen yerine getirmeye çalışmak ve gereksiz sorularla işi yokuşa sürmemektir. Nitekim ayet $^{33}$ ve hadislerde ${ }^{34}$ bu hususa dair uyarılar bulunmakta ve gereksiz yere soru sormanın, işi yokuşa sürmenin doğru olmadığı beyan edilmektedir.

\subsection{Neshedilen Hükümleri Belirtmesi}

Nesih olgusu, bunun Kur’ân’da bulunması ve Kur'ân'ın sünnetle, sünnetin Kur’ân’la neshedilmesi, çok tartışılmış ve tartışılmaya devam edilen önemli tefsir konularındandır. Âlimlerin çoğuna göre hem Kur’ân ayetlerinin birbirini neshetmesi hem de Kur’ân’ın sünnetle, sünnetin Kur’ân’la neshedilmesi caiz ve vakidir. ${ }^{35}$ Müfessirin sünnetle yaptığı tefsirlerin bir kısmı, bu konuyla ilgilidir. Müfessir, bazen

30 el-Bakara 2/71.

31 Hadisle ilgili bk. Ahmed b. Ali İbn Hacer el-'Askalânî, Fethu'l-bârî şerhu Sahîhi’l-Buhârî (Beyrut: Dârü'l-Ma'rife, ts.), 13/261.

32 Tillovî, Ebde 'u'l-beyân, 44.

33 تEy iman edenler! Açılandığl takdirde, sizi üzecek olan şeylere dair soru sormayın.” el-Mâide 5/101.

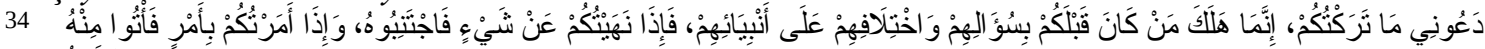
"Sizi kendi halinize bıraktığım sürece siz de beni kendi halime bırakın. Çünkü sizden öncekiler peygamberlerine çok soru sormaları ve aldıkları cevaplar konusunda ihtilâf etmeleri sebebiyle helâk oldular. Bundan dolayı size, bir şey yasakladığım zaman onu terk edin, bir şey emrettiğim zaman onu gücünüz yettiğince yerine getirin." Ebû Abdullah Muhammed b. İsmail elBuhârî, Sahîhu'l-Buhârî, thk. Muhammed Züheyr b. Nasırunnasır (b.y.: Dâru Tavkı'n-Necât, 1422/2001-2002), "I'tisâm”, 2.

35 Muhammed b. Muhammed el-Mâtürîdî, Te 'vîlâtü Ehli’s-sünne, thk. Mecdî Bâslûm (Beyrut: Dârü'lKütübi’l-'İlmiyye, 2005), 1/531-532. 
hadisin ayeti neshettiğini açıkça beyan etmekte, bazen de buna değinmemektedir. Bu konuyu da örnekler üzerinde açıklamaya çalışacağız.

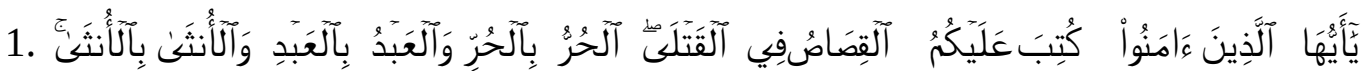
"Ey iman edenler! Öldürülenler hakkında size kısas farz kılındı. Hüre karşı hür, köleye karşı köle, kadına karşı kadın (kısas edilir). Ancak kim kardeşi tarafından (kısas edilmekten) affedilirse, aklın ve dinin gereklerine uygun yol izlemek ve güzellikle diyet ödemek gerekir.”36

Müfessir, ayetin kısas konusunda insanları kategorilere ayırdığını ve bu nedenle üst sınıftaki kişinin (hür, erkek) alt sınıfta bulunan birisine karşı kısas edilmeyeceğini söylemektedir. Buna göre erkeğin kadına karşı kısas edilmemesi gerekir. Ancak müfessir, sünnete göre erkeğin kadına karşı kısas edileceğini söylemektedir. Bu tefsire göre sünnet, ayetin erkeğin kadına karşı kısas edilmemesine dair kısmını neshetmiştir. ${ }^{37}$ Müfessir, bu tefsirini yaparken sadece ilgili hükmün sünnette bulunduğunu söylemekte, ne tefsirin metninde ne de dipnotunda gerekçe gösterdiği hadise/hadislere yer vermektedir. Erkeğin kadına karşı kısas edileceğini beyan eden iki rivayet nakledilmiştir. Birincisine göre Hz. Peygamber, Yemenlilere bir mektup göndermiş ve ilgili mektubunda erkeğin kadına karşı öldürüleceğini beyan etmiştir. ${ }^{38}$ Diğer rivayete

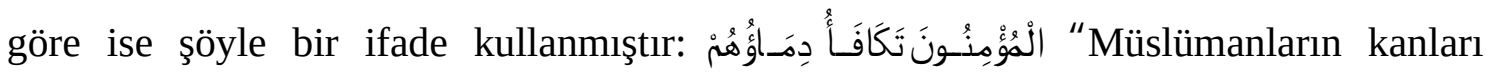

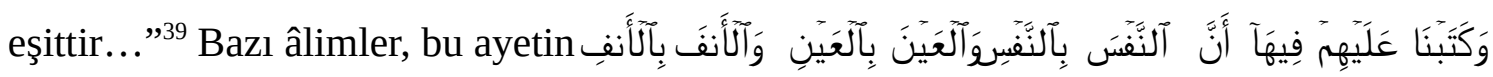

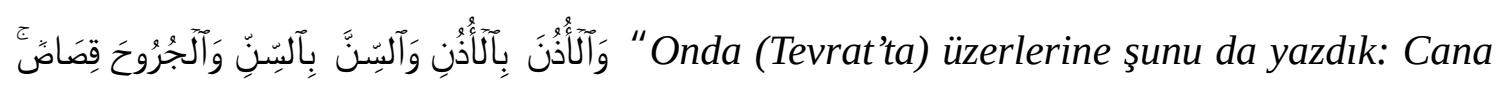
can, göze göz, buruna burun, kulağa kulak, dişe diş kısas edilir. Yaralar da kısasa tabidir." ${ }^{40}$ ayetiyle mensûh olduğunu, dolayısıyla hürün köleye, erkeğin kadına ve Müslümanın zimmîye karşı kısas edileceğini ifade etmişlerdir. ${ }^{41}$

36 el-Bakara 2/178.

37 Tillovî, Ebde 'u'l-beyân, 79.

38 Ahmed b. Şuayb en-Nesâî, es-Sünen, thk. Abdülfettâh Ebû Gudde (Halep: Mektebetü'l-Metbû‘âti'lİslâmiyye, 1986), "Kasâme", 45.

39 Nesâî, "Kasâme", 12.

40 el-Mâide 5/45.

41 Ahmed b. Muhammed es-Sa'lebî, el-Keşf ve’l-Beyân, thk. Ebû Muhammed b. 'Âşûr (Beyrut: Dâru İhyâ'i’t-Türâsi'l-'Arabî, 2002), 2/53-54. 


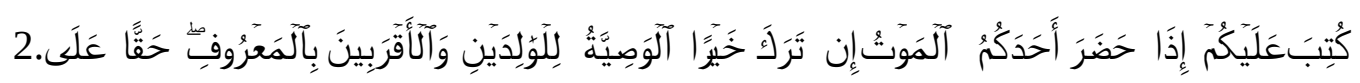
"Sizden birinize ölüm gelip çattığı zaman, eğer geride bir hayır (mal) bırakmışsa, anaya, babaya ve yakın akrabaya meşru bir tarzda vasiyette bulunması Allah'a karşı gelmekten sakınanlar üzerinde bir hak olarak- size farz kılındı.”42

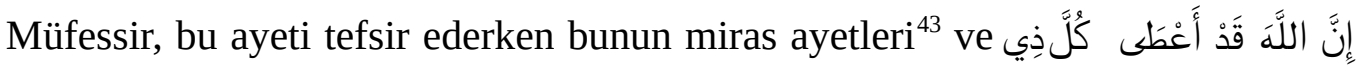

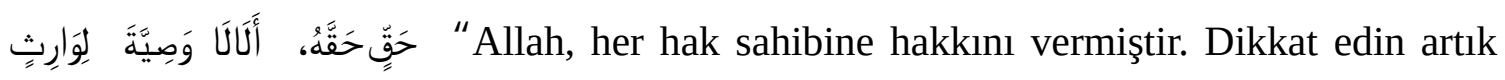
mirasçıya vasiyet yoktur." ${ }^{44}$ hadisi ile neshedildiğini ifade etmektedir. ${ }^{45}$ Sünnetin Kur'ân'ı neshetmediğini söyleyen âlimler ise ilgili ayetin miras ayetiyle mensûh olduğunu, sünnetin ise durumu beyan ettiğini ifade etmektedirler. ${ }^{46}$

\subsection{Ayetin Yanlış Anlaşılmasının Önüne Geçmesi}

Kur’ân’ın doğru anlaşılmasının en önemli kaynaklarından nüzul sebebi ve nüzul ortamına ait rivayetler içinde değerlendirilebilecek sünnettir. Müfessir, bazen sünnetten yararlanarak ayetin yanlış anlaşılmasını önlemeye çalışmaktadır. Müfessirin bu şekilde yaptığı tefsirlere bazı örnekler:

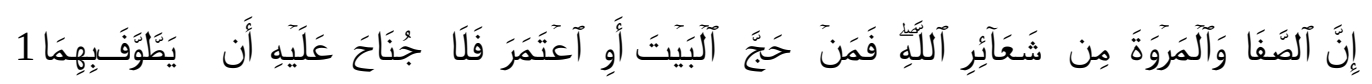

“Şüphesiz Safa ile Merve, Allah’ın (dininin) nişanelerindendir. Onun için her kim hac ve umre niyetiyle Kâbe'yi ziyaret eder ve onları da tavaf ederse, bunda bir günah yoktur."47

Hac ve umre görevlerinden biri de Safa-Merve tepeleri arasında yedi defa gidip gelmektir. Bu görevi beyan eden bu ayette Safa-Merve tepelerine tavaf yapmakta sakınca bulunmadığı ifade edilmektedir. Bu ifade, tek başına Safa-Merve arasında gidip gelmenin farz, vacip veya sünnet olduğunu göstermemektedir. Müfessir, Safa-Merve arasında yedi defa koşmanın Hanbelî dışındaki mezheplere göre vacip olduğunu

42 el-Bakara 2/180.

43 Bk. en-Nisâ 4/11-12, 176.

44 Muhammed b. Yezîd İbn Mâce, es-Sünen, thk. Muhammed Fuâd Abdülbâkî (b.y.: Dâru İhyâ'i'lKütübi'l-'Arabiyye, ts.), "Vasâyâ"” 6.

45 Tillovî, Ebde 'u’l-beyân, 80.

46 Muhammed b. İdris eş-Şâfi'î, el-Üm (Beyrut: Dârü’l-Ma'rife, 1990), 4/103-104.

47 el-Bakara 2/158. 
söylemekte; Ensâr'ın Câhiliyye'de bu tepelerde bulunan putların etrafında tavaf yaptıklarını, bu kötü âdeti hatırlamamak için bu tepeler arasında gidip gelmeyi

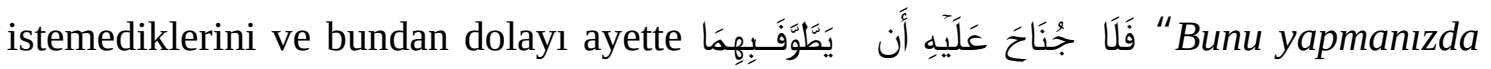
bir sakınca yoktur.” ifadesi kullanıldığını kaydetmektedir. ${ }^{48}$ Müfessir, Hz. Peygamber’in “Sa‘y edin. Çünkü Allah, size sa‘yi farz/vacip kılmıştır."49 dediğini kaydederek ayetin yanlış anlaşılmasının önüne geçmektedir. Müfessir, ayrıca bu görevin iki tepe arasında “yedi defa” gidip gelmekle yerine getirileceğini ve muhtemelen bunu ifade etmek için يَطُوفَ لِ yerine (bir şeyin etrafında

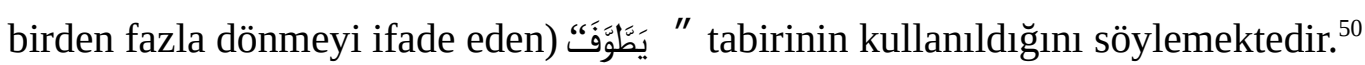

\section{5. Âmmı Tahsis Etmesi}

Kur’ân, bazı hususları genel bir şekilde ifade ederek tahsis görevini sünnete bırakmaktadır. Müfessir de söz konusu ayetlerin tefsirinde Hz. Peygamber’in sünnetine başvurarak ayetlerin genel olmadığını belirtmektedir. Müfessirin bu şekilde yaptığı tefsirlere birkaç örnek:

$$
1 \text { " (Allah), size ancak }
$$
leş, kan, domuz eti ve Allah'tan başkası adına kesileni haram kıldı."51

$\mathrm{Bu}$ ayette ölü etinin haram olduğu beyan edilmekte ve herhangi bir istisnaya yer verilmemektedir. Bu da bütün ölü hayvan etlerinin haram olduğu düşüncesine neden olmaktadır. Müfessir, ölü balık ve çekirgenin helal olduğunu; zira bu konuda bir hadisin bulunduğunu söyleyerek ayetteki genel ifadeyi sünnetle tahsis etmektedir. ${ }^{52}$ Hadis

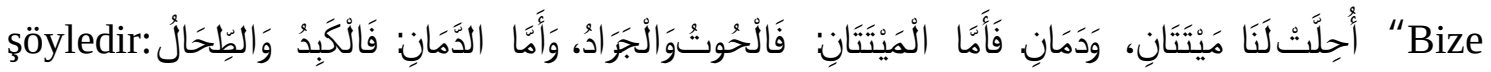
iki ölü ve iki kan helal kılınmıştır; balık ve çekirge ile karaciğer ve dalak.”53 Bu hadis, aslında "kan”ı da tahsis etmektedir. Ancak müfessir bu ifadeyi akıcı kanın haram

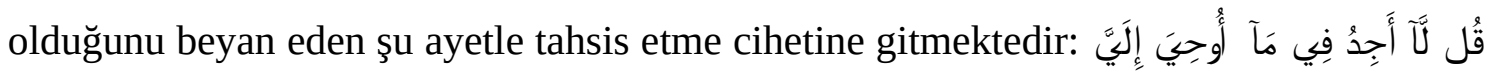

48 Tillovî, Ebde 'u’l-beyân, 73.

49 Ahmed b. Hanbel, el-Müsned, thk. Şuayb el-Arnâût vd. (b.y.: Müessesetü’r-Risâle, 2001), 45/363.

50 Tillovî, Ebde 'u'l-beyân, 73.

51 el-Bakara 2/173.

52 Tillovî, Ebde 'u'l-beyân, 77.

53 Ahmed b. Hanbel, el-Müsned, 10/16. 


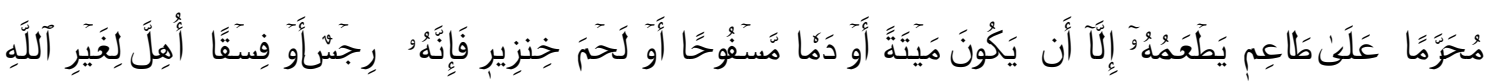
بِّ “De ki: 'Bana vahyolunan (Kur’ân’da) bir kimsenin yiyecekleri arasında leş, akıtılmış kan, domuz eti -ki o şüphesiz necistir- ya da Allah’tan başkası adına kesilmiş bir hayvandan başka, haram kılınmış bir şey bulamıyorum." ${ }^{\text {4 }} \mathrm{Bu}$ da müfessirin Kur’ân’la tefsir yapmaya önem verdiğini, Kur’ân’da bir delil bulamadığı zaman sünnete ve diğer kaynaklara müracaat ettiğini göstermektedir.

\subsection{Mutlakı Takyit Etmesi}

Allah Teâlâ, Kur'ân’da her konuyu kayıtlarıyla birlikte anlatmamakta, bazı hususları mutlak zikrederek gerisini sünnete bırakmaktadır. Müfessirin bu kapsamda yaptığı tefsirleri bir örnek üzerinde izah etmeye çalışacağız.

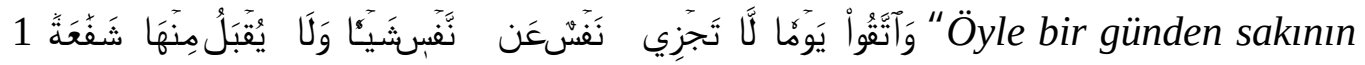
ki, o gün hiç kimse bir başkası adına bir şey ödeyemez. Hiçbir kimseden herhangi bir şefaat de kabul olunmaz." 55

Müfessir, şefaatin sadece kâfirler için kabul edilmeyeceğini, nakledildiği gibi günahkâr müminler için şefaat yapılacağını belirtmektedir. ${ }^{56}$ Zira bir rivayete göre Hz.

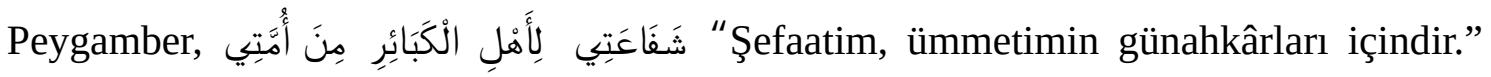
demiştir. ${ }^{57}$ Muhtemelen müfessir, "nakledildiği gibi” derken bu ve buna benzer hadisleri kastetmektedir. Müfessir, daha önce de ifade ettiğimiz gibi tefsirin muhtasar olmasına azami dikkat etmekte ve bunun için hadis metinlerine yer vermemektedir. Müfessir, eserinin başında kaynaklarını vererek meseleleri tetkik etmek isteyenleri ilgili kaynaklara yönlendirmektedir. Nitekim müfessirin kaynaklarından Medârikü 't-tenzîl'de bu hadis yer almaktadır. ${ }^{58}$

4 el-En‘âm 6/145.

55 el-Bakara $2 / 48$.

56 Tillovî, Ebde 'u'l-beyân, 38.

57 İbn Mâce, "Zühd", 37.

58 Abdullah b. Ahmed en-Nesefî, Medârikü 't-tenzîl ve hakâ'iku't-te'vîl, thk. Yusuf Ali Bedîvî (Beyrut: Dârü'l-Kelimü't-Tayyıb, 1998), 1/87. 


\subsection{Mücmeli Tebyin Etmesi}

Müfessirin sünnete başvurma nedenlerinden biri de Kur'ân’da mücmel birakılan ayetlerdir. Bu başlıkta müfessirin bu tür tefsirlerine iki örnek vermeye çalışacağız.

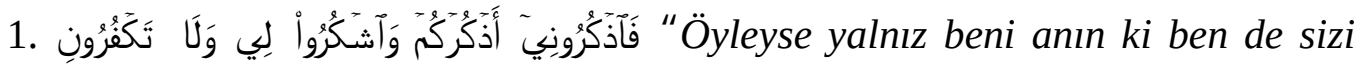
anayım. Bana şükredin, sakın nankörlük etmeyin." "59

Bu ayette "Beni anın ki ben de sizi anayım.” buyrulmakta; ancak Allah Teâlâ'yı nasıl ve ne şekilde anmamız gerektiği konusunda bilgi verilmemektedir. Bunun için müfessirler birçok anma şekline yer vermektedirler. ${ }^{60}$ Müfessir, bu ayeti tefsir ederken bir hadis-i kutsiye başvurarak ayetteki icmali tebyin etmektedir. ${ }^{61}$ İlgili hadis şöyledir:

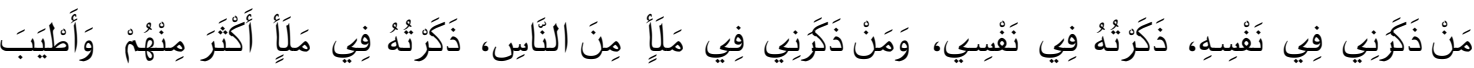
"Kim beni gizli anarsa ben de onu gizli anarım, kim beni bir topluluk içinde anarsa ben onu daha hayırlı bir toplulukta anarım.” ${ }^{62}$ Müfessir, bu tefsirine yazdığı ve Kalâ'idü'lcumân adını verdiği notlarında ilgili hadisi şöyle yorumlamaktadır: “Onu gizli anarım.' yani ona verdiğim sevaba ve fazilete kimseyi vakıf kılmam. 'Onu daha hayırlı bir toplulukta anarım.’ yani ona verdiğim sevabı ve fazileti meleklere veya peygamberlere bildiririm., ${ }^{\prime 63}$

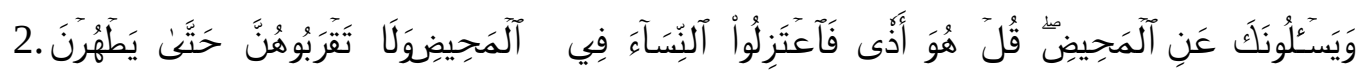

"Sana kadınların ay hâlini sorarlar. De ki: 'O bir ezadır (rahatsızlıktır). Ay hâlinde kadınlardan uzak durun. Temizleninceye kadar onlara yaklaşmayın.”64

Müfessir, bu ayeti tefsir ederken adetli kadınlara yaklaşmama emrinin cinsel ilişkiye yönelik olduğunu; zira Hz. Peygamber’in bunun dışında kalan hususların haram olmadığını belirttiğini, ancak hadisten dolayı göbekle diz arasının âlimlerin çoğu tarafından haram kabul edildiğini ifade etmektedir. Müfessir burada ayetteki icmali

\footnotetext{
59 el-Bakara 2/152.

60 Nasr b. Muhammed es-Semerkandî, Tefsîru Ebi'l-Leys es-Semerkandî, thk. Mahmûd Mutricî (Beyrut: Dârü'l-Fikr, ts.), 1/104.

61 Tillovî, Ebde 'u'l-beyân, 66.

62 Ahmed b. Hanbel, el-Müsned, 14/291.

63 Ebü'l-Berekât Muhammed Bedreddin et-Tillovî, Kalâ'idü'l-cumân fî cîdi Ebde 'i’l-Beyân (Ebde 'u'lbeyân hâmişinde) (Beyrut: el-Mektebetü'l-Hâşimiyye, 2016), 72.

64 el-Bakara 2/222.
} 
sünnetle tebyin etmekte; ancak bu konuda sadece bir hadisin bulunduğunu söylemekte, dipnotta ise Hz. Peygamber'in adetli eşine yaklaşma konusunu soran birisine لَتَُشََّ عَلَيْهَا "Eteğini giysin, etek üstü sana helaldir.”65 dediğini naklederek hadisin metnine yer vermektedir. ${ }^{66}$

\subsection{Müteşâbih Ayetleri Tevil Etmesi}

Kur'ân ayetlerinin bir kısmı muhkem, bir kısmı ise müteşâbihtir. ${ }^{67}$ Allah Teâlâ'nın yarattıklarına benzediği vehmine neden olan ayetler, müteşâbih kabul edilmiştir. Selef âlimleri, bu tür ifadeleri olduğu gibi bırakmanın, tefsir etmemenin gerekli olduğunu söylemişlerdir. ${ }^{68}$ Birçok âlim ise bunları Allah Teâlâ'nın şanına yaraşır bir şekilde tevil etmeyi caiz, hatta gerekli görmüşlerdir. ${ }^{69}$ Kur’ân'ın Arapça olması ve ilk muhataplarının onu anlaması bu tür ayetleri olduğu gibi bırakmanın doğru olmadığını göstermektedir. Taberî’nin (öl. 310/923) de ifade ettiği gibi Allah Teâlâ’nın, muhataplarının anlamadığı bir şekilde konuşması söz konusu değildir. Zira bu durum, Allah Teâlâ'nın meramını açıklamaktan, muhatabına bilgi vermekten aciz olduğu anlamına gelmektedir. ${ }^{70}$ Bunun için Kur’ân’ın her ifadesini ilk muhatap kitlenin anlayışına göre tefsir etmek, son derece önem arz etmektedir. Müfessirin bu konudaki tefsirlerine bir örnek vererek sonraki konuya geçeceğiz.

1 “Onun Kürsî’si, bütün gökleri ve yeri kaplayıp kuşatmıştır."71

Müfessir, müteşâbih kabul edilen bu ayetteki "Kürsî” kelimesini tevil etme cihetine gitmekte ve sünnetle tefsir metodunu kullanarak bu tevilini bir hadise dayandırmaktadır. Nitekim Kürsî’nin gökleri ve yeri kuşatmasının Allah Teâlâ'nın

65 Mâlik b. Enes, el-Muvatta, thk. Muhammed Mustafa el-A'zamî (Beyrut: Dâru İhyâ'i'tTürâsi'l-‘Arabî, 1985), "Vukûtü’s-Salah", 33.

66 Tillovî, Ebde 'u’l-beyân, 97-98.

67 Bk. Âl-i 'İmrân 3/7.

68 Abdurrahman b. Mervân el-Kanâzi'î, Tefsîrü'l-Muvatta, thk. 'Âmir Hasan Sabrî (Katar: Dârü’nNevâdir, 2008), 1/85.

69 Ali b. Muhammed el-Mâverdî, en-Nüket ve'l- 'uyûn, thk. es-Seyyid b. Abdülmaksûd (Beyrut: Dârü'lKütübi'l-'İlmiyye, ts.), 2/51-52.

70 Ebû Cafer Muhammed b. Cerîr et-Taberî, Câmi'u'l-beyân 'an te'vîli âyi'l-Kur'ân, thk. Ahmed Muhammed Şakir (b.y.: Müessesetü'r-Risâle, 2000), 1/11.

71 el-Bakara 2/255. 
azametinden kinaye olduğunu, bu konuda bir hadisin de bulunduğunu, hadiste ayrıca arşın Kürsî’yi kuşattığının ifade edildiğinii ${ }^{72}$ söylemektedir. ${ }^{73}$

\subsection{Kur’ân'da Olmayan Bilgilere Yer Vermesi}

Daha önce de açıkladığımız gibi sünnet bazen Kur’ân’a ek bilgiler vermektedir. $\mathrm{Bu}$ başlık altında müfessirin bu çerçevede yaptığı tefsirlere örnekler vermeye gayret edeceğiz. Müfessir, eserinin dipnotunda bu türden çok sayıda tefsire imza atmaktadır. Ancak biz örneklerimizi dipnottaki bilgilerden değil; tefsirin kendisinden vereceğiz.

1. Hani meleklere, 'Âdem'e secde edin.' demiştik de İblis hariç hepsi hemen secde ettiler. O ise (bundan) kaçındı, büyüklük tasladı ve kâfirlerden oldu."74

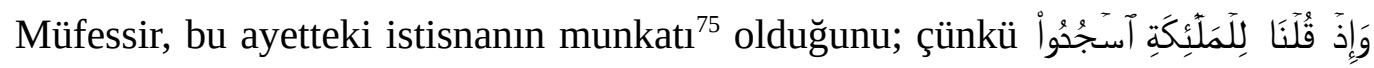

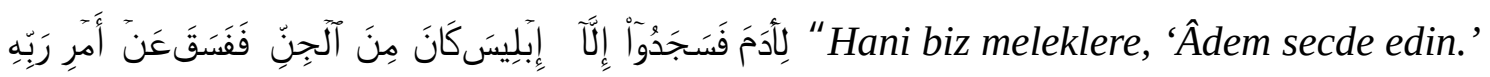
dedik de İblîs'ten başka hepsi secde ettiler. $O$ ise cinlerdendi de rabbinin emrinin dışına çıktı.” ayeti ve diğer delillerden İblîs’in cinlerin atası veya onlardan olduğunun açıkça ortaya çıktığını söylemektedir. İblîs'in cinlerden olduğuna dair bilgi, müfessirin de belirttiği gibi Kur’ân’da geçmektedir. Ancak onun cinlerin atası olduğuna yönelik malumat, Kur’ân’da değil; hadislerde yer almaktadır. Nitekim Mu‘âviye b. el-Hakem’in (öl. ?) sorusu üzerine Hz. Peygamber, Âdem ve Havvâ’nın insanların; İblis ve eşinin ise cinlerin anne-babası olduğunu söylemiştir. ${ }^{76}$ Müfessir, söz konusu bilginin hadiste geçtiğini kaydetmemekte, sadece böyle bir bilginin nakledildiğini ifade etmektedir. Müfessir, ayrıca bu ayetteki istisnanın muttasıl da olabileceğini; zira İblîs’in melek olduğuna/sayıldığına dair görüşlerin de bulunduğunu ve bu görüşün bazı âlimler

72 Ebû Hâtim Muhammed İbn Hibbân, el-ïhsân fî takrîbi Sahîhi İbn Hibbân (Beyrut: Müessesetü’rRisâle, 1988), 2/77.

73 Tillovî, Ebde 'u'l-beyân, 112-113.

74 el-Bakara 2/34.

75 İstisnâ, "muttasıl" ve "munkatı" olmak üzere iki kısma ayrılmaktadır. Muttasıl istisnâda müstesnâ (çıkarılan), müstesnâ minhin (kendisinden çıkarılan) içinde iken, munkatı istisnâda ise bu durum farazi olarak kabul edilmektedir. İbrahim b. Musa eş-Şâtıbî, el-Makāsıdü'ş-şâfiye fì şerhi'l-Hulâsati'lkâfiye, thk. Abdurrahman b. Süleyman el-'Useymîn vd. (Mekke: Ma'hedi'l-Buhûsi'l-'İlmiyye, 2007), $3 / 345$.

76 Ali b. Ebû Bekir el-Heysemî, Mecma 'u'z-zevâid (Beyrut: Dârü'l-Fikr, 1412/1991-1992), 1/193. 
tarafından tercih edildiğini ifade etmektedir. ${ }^{77}$ Müfessir, işarette bulunduğu bu hadislerle ilave bilgilere yer vermektedir. Zira ayette İblîs’in kimliği söz konusu edilmemektedir.

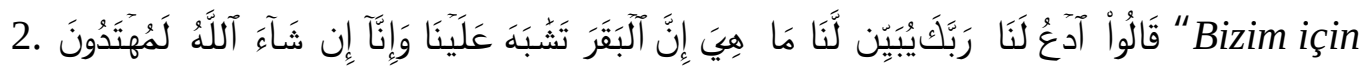
Rabbine dua et de onun nasıl bir şey olduğunu bize açıklasın. Çünkü sığırlar, bizce, birbirlerine benzemektedir. İnşallah buluruz.' dediler."78

Bu ayet, Allah Teâlâ’nın İsrâiloğullarından bir sığır kesmelerini istediğini beyan eden kıssada geçmektedir. İsrâiloğulları, istenen sığırın ne gibi özelliklere sahip olduğunu sormuş, belirtilen her özellikten sonra yenilerini talep etmiş ve sonunda inşallah demişlerdir. Müfessir, bu ayeti tefsir ederken Hz. Peygamber’in لَو لم يستثنوا لما "Eğer inşallah demeselerdi kıyamete kadar istenen (sığırı) bulmayacaklardı.”79 dediğini ifade ederek sünnetle ayete ek bilgiler vermektedir. ${ }^{80}$

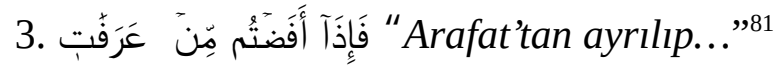

Müfessir bu ayeti tefsir ederken Arafat vakfesinin hac ibadeti içindeki önemini vurgulamak için bir hadise başvurarak ayette verilmeyen ilave bilgiler aktarmaktadır. ${ }^{82}$ Söz konusu hadiste Hz. Peygamber, الْحَجُج عَرَفَة "Hac, Arafat’tır.”83 diyerek Arafat vakfesi olmadan hacdan bahsedilemeyeceğini belirtmiştir.

\section{SONUÇ}

Molla Bedreddin Sancar’ın, ilmin revaçta olduğu, çok sayıda âlimin ve ilim merkezinin bulunduğu Siirt bölgesinde ve Osmanlı'nın tesirinin devam ettiği bir dönemde dünyaya gelmesi onun ilme yönelmesine vesile olmuştur. Ayrıca ilim ehli bir aileden olması, onun erken yaşlardan itibaren ilim tahsiliyle meşgul olmasını ve genç sayılabilecek bir yaşta iyi bir şekilde yetişmesini sağlamıştır. Nitekim daha okul çağına gelmeden dönemin medrese anlayışına göre tahsil hayatına başlamış ve ilkokulda

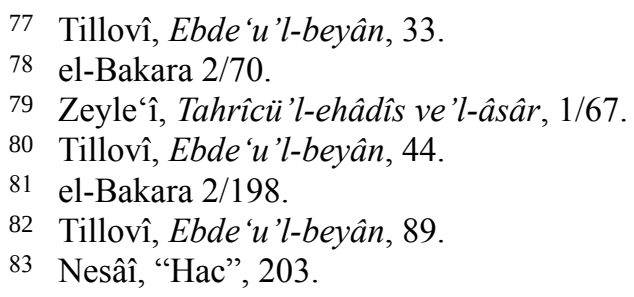


okuduğu sürece Arapça tahsilini devam ettirmiştir. Sancar, ilkokuldan mezun olmasıyla Tillo dışındaki medreselere gitme imkânına kavuşmuş ve bunu çok iyi değerlendirerek dönemin büyük âlimlerinden ders almaya çalışmıştır. Nihayetinde bölgenin en büyük âlimlerinden Molla Abdülhakim’den ilmi icazetini almıştır.

Sancar, öğrendiği ilimlerle halka hizmet etmeye ve talebe yetiştirmeye önem vermiştir. Nitekim 1959-1971 yılları arasında Tillo Ulu Camii’nde, 1971-1995 yıllarında ise Siirt Ulu Camii’nde İmam-Hatiplik görevinde bulunarak vaaz ve hutbeler aracılığıyla halkı irşat etmeye çalışmıştır. Öte yandan Tillo’da görev yaptığı süre boyunca Şeyh Mustafa el-Fânî Medresesi’nde, Siirt'te ise el-Fahr Medresesi'nde tedris faaliyetinde bulunarak Arapça ilimleri konusunda çok sayıda kişinin yetişmesine vesile olmuştur. Sancar, Siirt Ulu Camii’ndeki İmam-Hatiplik görevinden 1995 yılında yaş haddinden emekli olmasına rağmen cemaatin isteği üzerine bu camide Cuma hutbelerini okumaya ve Cuma namazlarını kıldırmaya devam etmiş, vakit namazlarını ise tedris faaliyetini sürdürdüğü el-Fahr Medresesi’nin mescidinde kıldırmaya başlamıştır.

Ebde ‘u’l-beyân tefsiri, klasik tefsirlerin bir nevi ihtisarıdır. Eser, uzun tefsirleri okumak için zamanı olmayan ve söz konusu tefsirlerde aktarılan malumattan az da olsa haberdar olmak isteyen okuyuculara yöneliktir. Ancak eserin çok muhtasar olması okuyucunun birçok ilim dalının bilgilerine vakıf olmasını gerektirmektedir. Zira eserde ilgili konulara sadece işaret edilmekte, bu da konuya yabancı olan okuyucunun müfessirin muradını anlamasını zorlaştırmaktadır. Eser, aynı zamanda medreselerde ders kitabı olarak okutulan Beyzâvî’nin Envârü't-tenzîl adlı eserin yerine okutabilecek bir tefsirdir. Zira tefsirde Kur’ân, medreselerde okutulan sarf, nahiv ve belagat ilimleri ile tefsir edilmesine önem verilmektedir. $\mathrm{Bu}$ da medrese öğrencilerine teorik olarak aktarılan söz konusu ilimlerle ilgili kuralların tatbik edilmesini sağlayacaktır. Nitekim Sancar, tefsirini kendi talebelerine okutmakta ve derslerde ilgili ilimlerin kuralları hakkında bilgiler vermektedir.

Kur’ân’ın en önemli beyanı, tefsiri, Hz. Peygamber’in sünnetidir. Bunun için Kur'ân’ı tefsir etmeye, ondan hükümler istinbât etmeye çalışan müfessirler, sünnete 
başvurmuş ve sünnet olmadan Kur'ân’ı doğru bir şekilde anlamanın çok zor, hatta imkânsız olduğunu ifade etmişlerdir.

Sancar, sünnete tabi olmanın ve her hâlükârda Hz. Peygamber’i örnek almanın gereği üzerinde duran ve kendi hayatını bu şekilde tanzim eden âlimlerdendir. Bunun için Kur’ân’ı sünnetten bağımsız ele almamıştır. Sancar, diğer birçok klasik müfessir gibi bazen sünnetle tefsir yaptığını söylememiş, hadislere yer vermemiş ve onlara işaret etmemiştir. Öte yandan, eserinin kısa olması için özellikle ilave bilgiler veren hadisleri metnin içinde değil, dipnotlarda kaydetmiştir. Yine klasik birçok müfessir gibi kaynak gösterdiği hadislerin senetlerine ve sshhat durumuna dair herhangi bir malumat vermemiştir.

Sancar, ayetlerde verilen bilgileri teyit etmek, verilmek istenen mesajı ortaya çıkarmak, neshedilen hükümleri belirtmek, ayetlerin yanlış anlaşılmasının önüne geçmek için sünnete başvurduğu gibi ayetlerin müteşâbihini tevil, âmmını tahsis, mutlakını takyid, mücmelini tebyin etmek için de sünneti kullanmıştır. Öte yandan ayetlerde verilemeyen; ancak ihtiyaç duyulan kimi bilgileri de sünnet vasıtasıyla aktarmaya çalışmıştır. 


\section{KAYNAKÇA}

Ahmed b. Hanbel. el-Müsned. thk. Şuayb el-Arnâût vd. 45 Cilt. b.y.: Müessesetü'rRisâle, 2001.

Akkuş, Mehmet. “Ahmet Emre Yetkin’in Siirtli Molla Bedreddin Sancar’a Gönderdiği Şiirler”. Uluslararası Amasya Âlimleri Sempozyumu. ed. Şuayip Özdemir Ayşegül Gün. 2/11-21. Ankara: KIBATEK Yayınları, 2017.

Aydın, M Âkif. “Mehir”. Türkiye Diyanet Vakfı İslâm Ansiklopedisi. 28/389-391. Ankara: TDV Yayınları, 2003.

Buhârî, Ebû Abdullah Muhammed b. İsmail. Sahîhu'l-Buhârî. thk. Muhammed Züheyr b. Nasırunnasır. 9 Cilt. b.y.: Dâru Tavkı'n-Necât, 1422/2001-2002.

Cürcânî, Seyyid Şerîf. et-Ta ‘rîfât. Beyrut: Dârü’l-Kütübi’l-‘İlmiyye, 1983.

Çağlar, Hasan. Bedreddin Sancar ve Ebdeu'l-beyân li cemîi âyi'l-Kur'ân Adlı Tefsiri. Şanlıurfa: Harran Üniversitesi, Sosyal Bilimler Enstitüsü, Yüksek Lisans Tezi, 2010.

Derveze, Muhammed İzzet. et-Tefsîrü'l-hadîs. 10 Cilt. Kahire: Dâru İhyâ'i’lKütübi’l-‘Arabiyye, 2. Basım, ts.

Erman, Uğur. "Siirt Medreselerinde İcâzetnâme Sonrası Okutulan Eserler ve İçerikleri”. Siirt Üniversitesi Sosyal Bilimler Enstitüsü Dergisi 10 (2017), 572-598.

Heysemî, Ali b. Ebû Bekir. Mecma ‘u’z-zevâid. 10 Cilt. Beyrut: Dârü’l-Fikr, 1412/19911992.

İbn Hacer el-‘Askalânî, Ahmed b. Ali. Fethu’l-bârî şerhu Sahîhi’l-Buhârî. 13 Cilt. Beyrut: Dârü’l-Ma'rife, ts.

İbn Hıbbân, Ebû Hâtim Muhammed. el-İhsân fî takrîbi Sahîhi İbn Hibbân. 18 Cilt. Beyrut: Müessesetü’r-Risâle, 1988.

İbn Mâce, Muhammed b. Yezîd. es-Sünen. thk. Muhammed Fuâd Abdülbâkî. 2 Cilt. b.y.: Dâru İhyâ'i’l-Kütübi'l-'Arabiyye, ts.

Kanâzi“î, Abdurrahman b. Mervân. Tefsîrü’l-Muvatta. thk. 'Âmir Hasan Sabrî. 2 Cilt. Katar: Dârü'n-Nevâdir, 2008.

Keşmîrî, Muhammed Enver Şâh Hüseynî. Feydu'l-bârî 'alâ Sahîhi'l-Buhârî. thk. Muhammed Bedir ‘Âlem el-Mîrtehî. 6 Cilt. Beyrut: Dârü’l-Kütübi’l-‘'̇lmiyye, 2005.

Mâlik b. Enes. el-Muvatta. thk. Muhammed Mustafa el-A'zamî. Beyrut: Dâru İhyâ'i’tTürâsi’l-‘Arabî, 1985.

Mâtürîdî, Muhammed b. Muhammed. Te’vîlâtü Ehli’s-sünne. thk. Mecdî Bâslûm. 10 Cilt. Beyrut: Dârü’l-Kütübi’l-‘İlmiyye, 2005. 
Mâverdî, Ali b. Muhammed. en-Nüket ve’l-‘uyûn. thk. es-Seyyid b. Abdülmaksûd. 6 Cilt. Beyrut: Dârü’l-Kütübi’l-'İlmiyye, ts.

Nesâî, Ahmed b. Şuayb. es-Sünen. thk. Abdülfettâh Ebû Gudde. 9 Cilt. Halep: Mektebetü'l-Metbû‘âti’l-İslâmiyye, 1986.

Nesefî, Abdullah b. Ahmed. Medârikü 't-tenzîl ve hakâ'iku't-te'vîl. thk. Yusuf Ali Bedîvî. 3 Cilt. Beyrut: Dârü'l-Kelimü’t-Tayyıb, 1998.

Öğmüş, Harun. “Bedreddin Sancar ve Ebdau’l-beyân Adındaki Tefsiri”. Uluslararası Şırnak ve Çevresi Sempozyumu. ed. M. Nesim Doru. 729-743. Ankara: MRK Baskl, 2010.

Râzî, Fahreddin Muhammed b. Ömer. Mefâtîhu'l-gayb (et-Tefsîrü'l-kebîr). 32 Cilt. Beyrut: Dâru İhyâ'i’t-Türâsi’l-‘Arabî, 3. Basım, ts.

Sa'lebî, Ahmed b. Muhammed. el-Keşf ve’l-Beyân. thk. Ebû Muhammed b. 'Âşûr. 10 Cilt. Beyrut: Dâru İhyâ'i’t-Türâsi'l-‘Arabî, 2002.

Selefî, Muhammed Lokman. Mekânetü’s-sünne fi't-teşrî‘i’l-İslâmî. Riyad: Dârü’d-Dâ‘î, 2. Basım, 1999.

Semerkandî, Nasr b. Muhammed. Tefsîru Ebi'l-Leys es-Semerkandî. thk. Mahmûd Mutricî. 3 Cilt. Beyrut: Dârü'l-Fikr, ts.

Şâfi‘î, Muhammed b. İdris. el-Üm. 8 Cilt. Beyrut: Dârü’l-Ma‘rife, 1990.

Şâtıbî, İbrahim b. Musa. el-Makāsıdü’ş-şâfiye fî şerhi'l-Hulâsati'l-kâfiye. thk. Abdurrahman b. Süleyman el-'Useymîn vd. 10 Cilt. Mekke: Ma'hedi'lBuhûsi’l-'İlmiyye, 2007.

Taberî, Ebû Cafer Muhammed b. Cerîr. Câmi ‘u'l-beyân 'an te’vîli âyi’l-Kur'ân. thk. Ahmed Muhammed Şakir. 24 Cilt. b.y.: Müessesetü’r-Risâle, 2000.

Tillovî, Ebü’l-Berekât Muhammed Bedreddin. Bedî‘u'l-beyân limâ 'asâ en yahfâ fi'lKur’ân. İstanbul: Kahraman Yayınları, 4. Basım, 2010.

Tillovî, Ebü’l-Berekât Muhammed Bedreddin. Ebde‘u’l-beyân li-cemî‘i âyi’l-Kur’ân. Beyrut: el-Mektebetü’l-Hâşimiyye, 4. Basım, 2016.

Tillovî, Ebü'l-Berekât Muhammed Bedreddin. el-Vasıyyetü'l-'âmme ve yelîhâ elVasâye'l-'aşere'd-dürer li'l-ebnâ'i'l- 'aşereti'l-gurer ve yelîhâ Şükürnâme. b.y.: y.y., ts.

Tillovî, Ebü’l-Berekât Muhammed Bedreddin. es-Sîretü'z-zâtiyye ve yelîhâ Vasıyettüh. İstanbul: Dârü’ş-Şafaka, 2013.

Tillovî, Ebü’l-Berekât Muhammed Bedreddin. Hulâsatü’l-beyân li-cemî‘i âyi’l-Kur'ân. b.y.: el-Mektebetü’l-Hâşimiyye, 2017.

Tillovî, Ebü'l-Berekât Muhammed Bedreddin. Kalâ'idü'l-cumân fî cîdi Ebde‘i’l-Beyân (Ebde‘u’l-beyân hâmişinde). Beyrut: el-Mektebetü’l-Hâşimiyye, 4. Basım, 2016. 
Turgay, Nurettin. "Müfessir Muhammed Bedreddin Sancar Hayatı Eserleri ve Tefsirciliği”. Uluslararası Siirt Sempozyumu. 266-274. İzmir: Birleşik Matbaa, 2007.

Türkoğlu, Adil. “Cumhuriyet Döneminde İlköğretimin Gelişimi”. Cumhuriyet Dönemi Eğitim Politikaları Sempozyumu. ed. Murat Parlak. 78-96. Ankara: TDK Yayınları, 2010.

Zeyle‘î, Abdullah b. Yusuf. Tahrîcü'l-ehâdîs ve’l-âsâr el-vâkı 'a fî Tefsîri’l-Keşşâf li’zZemahşerî. thk. Abdullah b. Abdurrahman es-Sa'd. 4 Cilt. Riyad: Dâru İbn Huzeyme, 1414/1993-1994. 